\title{
Biochar and clinoptilolite zeolite on selected chemical properties of soil cultivated with maize (Zea mays L.)
}

\section{Siti Wardah Zaidun a, Mohamadu Boyie Jalloh a,*, Azwan Awang a, Lum Mok Sam a, Normah Awang Besar b, Baba Musta b, Osumanu Haruna Ahmed c, Latifah Omar c}

a Faculty of Sustainable Agriculture, Universiti Malaysia Sabah, Sandakan, Sabah, Malaysia

b Faculty of Science and Natural Resources, Universiti Malaysia Sabah, Kota Kinabalu, Sabah, Malaysia

c Department of Crop Science, Faculty of Agriculture and Food Science, Universiti Putra Malaysia, Sarawak, Malaysia

\begin{abstract}
Increase in cost of chemical fertilizers encourages the use of soil amendments such as biochar and zeolites to improve soil fertility. In this study, biochar produced from empty fruit bunch-palm oil mill effluent (EFB-POME) and clinoptilolite zeolite were used as soil amendments to improve soil fertility. The field experiment was carried out for two planting cycles to determine the effects of different rates of EFB POME biochar $(0,10$, and $\left.20 \mathrm{t} \mathrm{ha}^{-1}\right)$, clinoptilolite zeolite $\left(0,1.25\right.$, and $\left.2.5 \mathrm{t} \mathrm{ha}^{-1}\right)$, and urea (60 and $\left.120 \mathrm{~kg} \mathrm{ha}^{-1}\right)$ on selected soil chemical properties of Tanjung Lipat (Typic Paleudults). Biochar produced from EFB-POME increase soil total N, P, K, Ca, and Mg. The higher soil total N, P, K, Ca, and $\mathrm{Mg}$ could be related to the increase in soil $\mathrm{pH}$, cation exchange capacity, and total organic carbon in soil with EFB-POME biochar but not with clinoptilolite zeolite. Thus, EFB-POME biochar was more suitable to be used in a tropical soil (Typic Paleudults) compared to clinoptilolite zeolite for improving the selected soil pH, CEC, TOC and available P, K, Ca and $\mathrm{Mg}$.
\end{abstract}

\section{Article Info}

Received : 26.01.2018 Accepted : 26.09.2018

Keywords: Biochar, clinoptilolite zeolite, EFB-POME, tropical acid soil, agriculture waste.

(C) 2019 Federation of Eurasian Soil Science Societies. All rights reserved

\section{Introduction}

Soils in the tropics are considered to be acidic, strongly weathered, low in nutrient reserves, and depend on their soil organic matter (SOM) for efficient nutrient recycling (Sanchez and Logan, 1992). Oxisols and Ultisols, which are acidic in their nature, are two major soil types in Malaysia and cover about $72 \%$ of the land (Anda et al., 2008). Generally, Oxisols and Ultisols are high Fe and Al oxides which contribute to the soil acidity (Schlesinger, 1997), low in effective cation capacity and nutrient reserves (Sanchez and Logan, 1992). In addition, these soils are degraded physically, chemically, and biologically due to human activities such as intensive farming, continuous and over usage of fertilizers and pesticides, removal of soil organic matter, as well as the topsoil layer (Scherr and Yadav, 1996). The conventional and most popular way to effectively increase soil fertility is to apply chemical fertilizers. This has led to increase in demand for fertilizers worldwide (IFA, 2014). Although chemical fertilizers are effective in increasing soil nutrient status and crop yield, their adverse effect in the long term and the harm to the environment is worth attention as fertilizers can be one of the sources of pollutants to soil and water.

For sustainable agriculture, biochar and zeolites can be used as soil amendments or conditioners to improve soil fertility. Biochar is a carbon rich organic material which originated from the terra-preta of Brazillian Amazon that has undergone pyrolysis process at relatively high temperature $\left(300-700^{\circ} \mathrm{C}\right)$ (Lehmann and Joseph, 2009). One of biochar's unique properties is high porosity, which can be favourable for improving

\footnotetext{
${ }^{*}$ Corresponding author.

Faculty of Sustainable Agriculture, Universiti Malaysia Sabah, Locked Bag No. 3, 90509 Sandakan, Sabah, Malaysia

Tel.: +6089248100

E-mail address: mbjalloh@ums.edu.my

e-ISSN: $2147-4249$ DOI: $10.18393 /$ ejss.468100
} 
soil water holding capacity and soil structure (Karhu et al., 2011; Vaccari et al., 2011). Crop productivity is positively affected by biochar addition as the amendment can increase and retain nutrients in the soil due to its high CEC (Cornelissen et al., 2013; Liang et al., 2006). Some types of biochar also possess high pH, a property which is favourable especially in acidic soils as biochar helps to buffer soil pH, substituting the use of liming to increase soil $\mathrm{pH}$, and indirectly increasing nutrient availability for crop nutrient uptake (Novak et al., 2009; van Zwieten et al., 2010; Nigussie et al., 2012). Biochar also improves soil quality by increasing soil biota as biochar is a suitable habitat for soil micro and macro organisms due to its high surface area and organic matter (Lehmann et al., 2011). In this study, biochar produced from empty fruit bunch and palm oil mill effluent (EFB-POME) was used. In 2010, Malaysia exported a total of 14.7 million tonnes of palm oil and palm oil products, contributing US\$ 4500 million revenue to the country (Bazmi et al., 2011). However, the biomass left from the palm oil production is as high as $90 \%$ because the oil extraction rate is only about $10 \%$ (Basiron and Weng, 2004). Due to the abundance of EFB and POME wastes in the oil palm industry, charring of these waste materials (to produce biochar) is one of the effective ways to return the biomass into the soil.

Clinoptilolite zeolite was also used in this study in combination with EFB-POME biochar for maize cultivation. Zeolites are hydrated aluminosilicates of alkaline and alkaline-earth minerals and their structure is made up of a framework of $\left[\mathrm{SiO}_{4}\right]^{-4}$ and $\left[\mathrm{AlO}_{4}\right]^{-5}$ tetrahedron linked to each other's corners by sharing oxygen atoms forming a 3-dimensional framework (Akbar et al., 1999). The 3-dimensional pore structures of zeolites are interconnected and form long wide channels for easy movement of ions and molecules into and out of the structures (Polat et al., 2004). The silicate $\left(\mathrm{SiO}_{4}\right)$ tetrahedron is a compromise between electrical neutrality and packing efficiency. To be electrically neutral, stable minerals require other positively charged accessory cations. This need for electrical neutrality and accessory cations leads to the important property of cation exchange capacity. Zeolites in natural conditions are combined with cations such as $\mathrm{Na}^{+}, \mathrm{K}^{+}, \mathrm{Ca}^{2+}$ and others (Navrotsky et al., 1995). In agriculture, zeolites are used as slow release fertilizer, soil amendment for pH buffering, increase CEC and fertilizer use efficiency, serve as water reservoir in the soil due to their high porosity and water filter in aquaculture systems (Polat et al., 2004).

Maize (Zea mays L.) is one of the important crops in the world, which serves as livestock's feed, food, and oil source for human consumption, and raw material for many agro-based industries. In 2014, Malaysia imported 3.2 billion tonnes of maize mainly from Argentina, Brazil, and India whereas domestic production was only 56,000 tonnes (Wahab and Rittgers, 2014). This study was carried out to determine the effects of biochar from empty fruit bunches and palm oil mill effluent (EFB-POME) and clinoptilolite zeolite on selected chemical properties of soil cultivated with maize.

\section{Material and Methods}

\section{Study site and selected soil chemical properties}

The field study was conducted in Faculty of Sustainable Agriculture, Universiti Malaysia Sabah (555'48.1"N, $118^{\circ} 00^{\prime} 29.8^{\prime \prime} \mathrm{E}$. The soil in the research plot belongs to Tanjung Lipat series which is equivalent to Typic Paleudults of the USDA system of soil classification. The soil is derived from sandstone and mudstone parent materials (Acres et al., 1975). The soil texture was classified as clay loam with clay content of $35 \%$. The soil chemical properties are presented in Table 1.

Table 1. Selected soil chemical properties of Tanjung Lipat (Typic Paleudults)

\begin{tabular}{ll}
\hline $\mathrm{pH}$ & 4.50 \\
Cation exchange capacity $\left(\mathrm{cmol}^{+} \mathrm{kg}^{-1}\right)$ & 2.10 \\
Total organic carbon (\%) & 3.15 \\
Total N (\%) & 0.65 \\
$\mathrm{NH}_{4}{ }^{+}\left(\mathrm{mg} \mathrm{kg}^{-1}\right)$ & 1.09 \\
$\mathrm{NO}_{3}{ }^{-}\left(\mathrm{mg} \mathrm{kg}^{-1}\right)$ & 0.02 \\
Available P $\left(\mathrm{mg} \mathrm{kg}^{-1}\right)$ & 1.56 \\
Exchangeable K $\left(\mathrm{mg} \mathrm{kg}^{-1}\right)$ & 15.20 \\
Exchangeable Ca $\left(\mathrm{mg} \mathrm{kg}^{-1}\right)$ & 87.00 \\
Exchangeable $\mathrm{Mg}\left(\mathrm{mg} \mathrm{kg}^{-1}\right)$ & 132.80 \\
\hline
\end{tabular}

\section{Field layout and site description}

The field experiment arranged in a randomized complete block design (RCBD) with three factors involved; EFB POME biochar $\left(0,10\right.$ and $\left.20 \mathrm{t} \mathrm{ha}^{-1}\right)$, clinoptilolite zeolite $\left(0,1.25\right.$ and $\left.2.5 \mathrm{t} \mathrm{ha}^{-1}\right)$ and urea (60 and $120 \mathrm{~kg}$ $\mathrm{ha}^{-1}$ ), replicated four times. The rates of biochar and zeolite were based on preliminary study pot study done 
previously and the properties of biochar and zeolite used in this study is presented in Table 2. Thai Super Sweet maize was used as a test crop in the field study. Each plot was $1.5 \mathrm{~m} \times 2.5 \mathrm{~m}$ in size with planting distance of $75 \times 25 \mathrm{~cm}$. The maize plants were harvested after reaching maturity, at 10 weeks after planting and planted for two cropping cycles. Fertilizers were applied in four splits. Triple Super Phosphate (TSP) and Muriate of Potash (MOP) fertilizers were applied at $60 \mathrm{~kg} \mathrm{ha}^{-1}$ of $\mathrm{P}$ and $\mathrm{K}$, respectively. Rainfall data was collected throughout the field trial from a weather station located approximately $5 \mathrm{~m}$ from the field trial plots (Figure 1).

Table 2. Properties of biochar and zeolite used in the study

\begin{tabular}{lrr}
\hline Properties & EFB-POME biochar & Clinoptilolite zeolite \\
\hline $\mathrm{pH}(\mathrm{KCl})$ & 7.45 & 8.56 \\
Cation exchange capacity $\left(\mathrm{cmol}^{+} \mathrm{gg}^{-1}\right)$ & 35.11 & 160.00 \\
Total C (\%) & 17.98 & 9.51 \\
Total N (\%) $_{\mathrm{NH}_{4}^{+}\left(\mathrm{mg} \mathrm{kg}^{-1}\right)}$ & 0.56 & 1.37 \\
$\mathrm{NO}_{3}^{-}\left(\mathrm{mg} \mathrm{kg}^{-1}\right)$ & 0.44 & 0.58 \\
Available P(\%) & 173.05 & 0.03 \\
Available K (\%) & 0.01 & $\mathrm{ND}$ \\
Available Ca (\%) & 0.27 & 2.26 \\
Available $\mathrm{Mg}(\%)$ & 0.08 & 2.56 \\
\hline
\end{tabular}
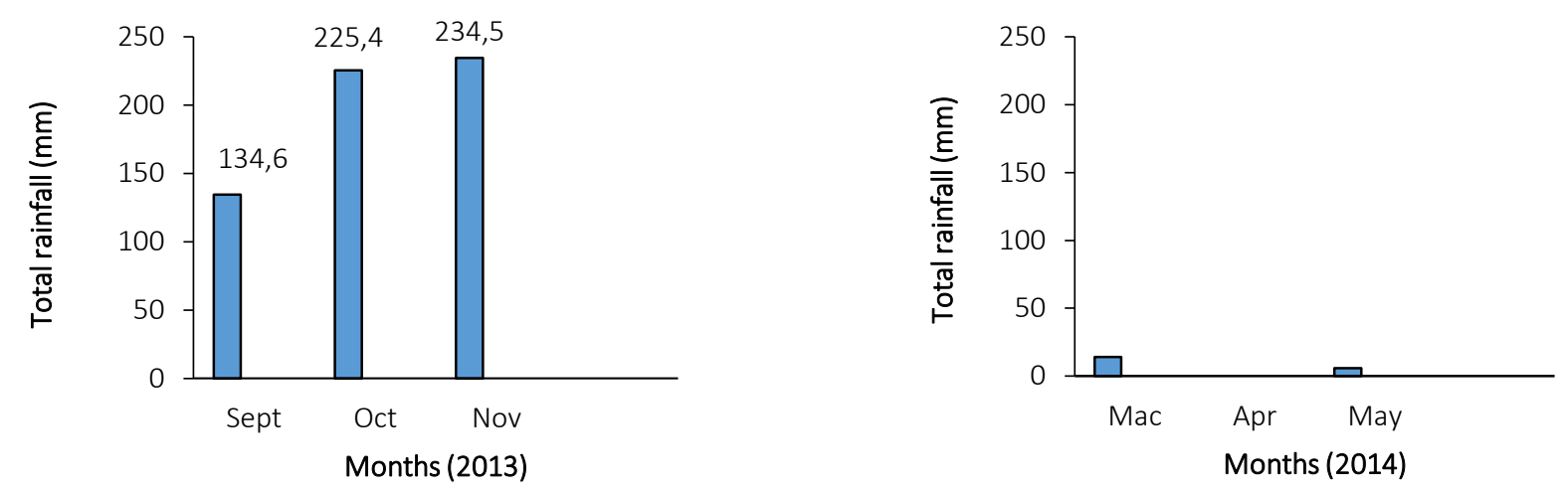

Figure 1. Monthly total rainfall distribution during the first and second cycles of maize cultivation

\section{Soil sampling and analysis}

Soil samples were randomly taken using an auger in the middle of each experimental plot up to $15 \mathrm{~cm}$ depth after every harvest. Soils were analyzed for total $\mathrm{N}, \mathrm{NH}_{4}{ }^{+}, \mathrm{NO}_{3}$, total organic $\mathrm{C}, \mathrm{pH}$, CEC, available $\mathrm{P}$, exchangeable $\mathrm{K}, \mathrm{Ca}$, and $\mathrm{Mg}$. The soil samples were air dried at room temperature, ground, and sieved to pass a $2 \mathrm{~mm}$ sieve. Soil available P was extracted using the Mehlich 1 method and the concentration was determined by colourimetry method (Pansu and Gauthevrou, 2006) using continuous flow auto analyser (SEAL Analytical AA3). Exchangeable $\mathrm{K}, \mathrm{Ca}$, and Mg were extracted using ammonium saturation method (Tan, 1995) and the concentrations determined with Inductively Coupled Plasma (Perkin Elmer ICP-OES model Optima 5300 DV).

\section{Statistical Analysis}

Analysis of variance (ANOVA) on all data at 5\% significant level was done using Statistical Package for Social Science (SPSS) version 21. Least Significant Different test was used to separate the means for variables that showed significant difference between the treatments for main effects.

\section{Results and Discussion}

\section{Soil pH, cation exchange capacity, and total organic carbon for the first and second planting cycles}

The main treatment effects on soil pH, total CEC, and TOC are presented in Table 3. In the first planting cycle, there was a significant interaction effect between all the three factors on soil pH and also a significant interaction effect between biochar and clinoptilolite zeolite on soil TOC. There was no significant interaction in the second planting cycle between all the factors for all the variables. However, biochar resulted in significant main effects on all the three variables (soil pH, CEC, and TOC) (Table 3). 
Table 3. The effects of biochar, clinoptilolite zeolite, and urea on soil properties for the first and second planting cycles

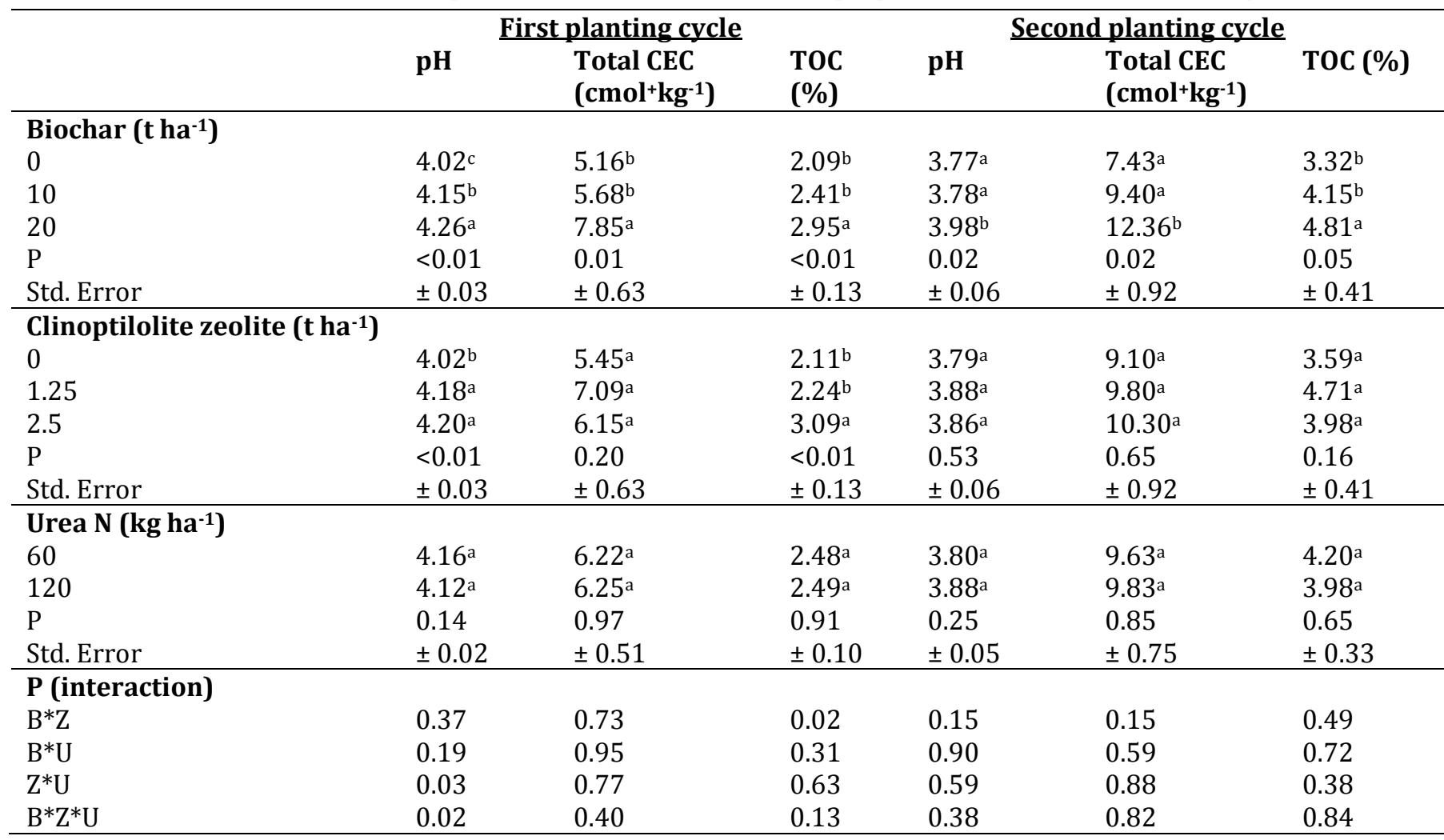

Means with the same letter within the columns are not significantly different $(\mathrm{P}<0.05)$ using LSD test. $\mathrm{P}=$ probability value from ANOVA. $\mathrm{B}^{*} \mathrm{Z}=$ biochar and zeolite interaction. $\mathrm{B}^{*} \mathrm{U}=$ biochar and urea interaction. $\mathrm{Z}^{*} \mathrm{U}=$ zeolite and urea interaction. $\mathrm{B}^{*} \mathrm{Z}^{*} \mathrm{U}=$ biochar, clinoptilolite zeolite, and urea interaction

The results of the treatments interaction on soil pH in the first planting cycles are shown in Figure 2. The plots with $60 \mathrm{~kg} \mathrm{ha}^{-1}$ urea and $1.25 \mathrm{t} \mathrm{ha}^{-1}$ clinoptilolite zeolite resulted in higher soil $\mathrm{pH}$ (4.05) compared with that of the unamended soil (3.93). However, increase in clinoptilolite zeolite rate $\left(2.5 \mathrm{t} \mathrm{ha}^{-1}\right)$ did not further increase soil $\mathrm{pH}$ (4.05). The soil $\mathrm{pH}$ was 3.98 in the plots with $10 \mathrm{t} \mathrm{ha}^{-1}$ biochar and the combined 10 $\mathrm{t}$ ha $^{-1}$ biochar and $1.25 \mathrm{t} \mathrm{ha}^{-1}$ clinoptilolite zeolite treatment resulted in an increase in soil pH to 4.26. However, in the plots with the same rate of biochar combined with $2.5 \mathrm{t}^{-1}$ zeolite, soil $\mathrm{pH}$ was lower (4.19). For the plots with $20 \mathrm{tha}^{-1}$ biochar, soil pH showed a value of 4.07. The combination treatment of $20 \mathrm{t}$ ha $^{-1}$ biochar and $1.25 \mathrm{t} \mathrm{ha}^{-1}$ zeolite increased soil $\mathrm{pH}$ to 4.3 and combining the same rate of biochar with higher rate of zeolite ( $\left.2.5 \mathrm{t} \mathrm{ha}^{-1}\right)$ resulted in the highest value of soil $\mathrm{pH}$ (4.55) (Figure 2).

The $120 \mathrm{~kg} \mathrm{ha}^{-1}$ of urea, soil without biochar, and clinoptilolite zeolite amendments resulted in lowest soil pH (3.89) and treating the soil with 1.25 and 2.5 t ha- $^{-1}$ resulted in increased soil pH (4.07 and 4.09, respectively). Soil pH was 4.12 when treated with $10 \mathrm{t} \mathrm{ha}^{-1}$ biochar and combining the $10 \mathrm{t} \mathrm{ha}^{-1}$ biochar with 1.25 and $2.5 \mathrm{t}$ $\mathrm{ha}^{-1}$ zeolite did not show significant changes in soil pH (4.13 and 4.12, respectively). Soil $\mathrm{pH}$ was 4.15 for the $20 \mathrm{t} \mathrm{ha}^{-1}$ biochar alone, but combining $20 \mathrm{t} \mathrm{ha}^{-1}$ biochar and $1.25 \mathrm{t} \mathrm{ha}^{-1}$ increased soil $\mathrm{pH}$ to 4.26 . However, the soil pH decreased (4.19) for the combination treatment of $20 \mathrm{t} \mathrm{ha}^{-1}$ biochar and $2.5 \mathrm{t} \mathrm{ha}^{-1}$ clinoptilolite zeolite.
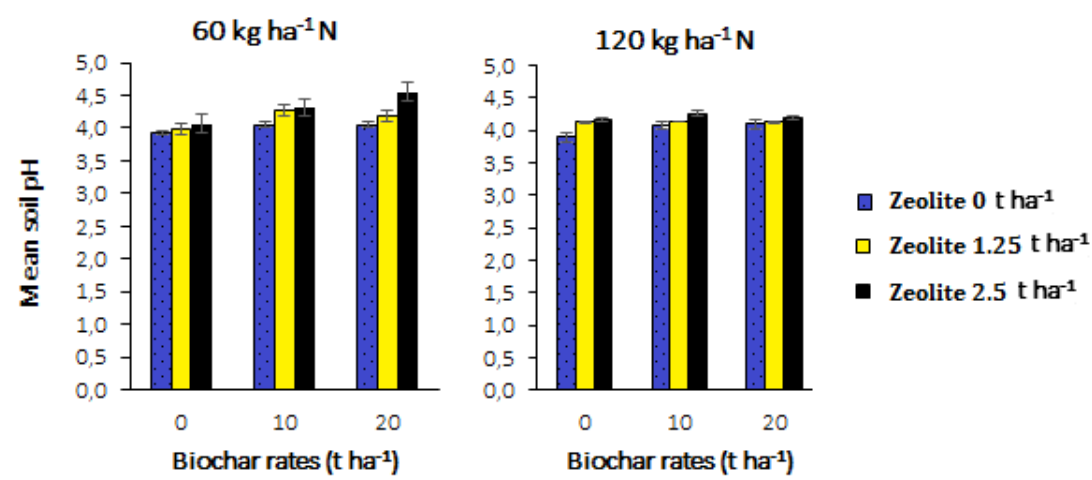

Figure 2. Soil pH for interaction between biochar, clinoptilolite zeolite, and urea in the first planting cycle. Error bars indicate standard error. 
The soil $\mathrm{pH}$ was higher with biochar and zeolite application at low $\mathrm{N}$ rate. Previous studies had reported the influence of biochar and zeolite in increasing soil pH due to liming effect. According to Polat et al. (2004) zeolites are marginally alkaline and fusing them with fertilizer helps in buffering soil pH levels, thus reducing the need for liming. van Zwieten et al. (2010) reported an increase in soil pH with biochar application. In this study, $\mathrm{N}$ fertilizer applied to the soil was in the form of urea. Upon hydrolysis, urea is converted to $\mathrm{NH}_{4}^{+}$, however, plants favour $\mathrm{N}$ in the form of $\mathrm{NO}_{3}{ }^{-}$and the oxidation of $\mathrm{NH}_{4}{ }^{+}$to produce $\mathrm{NO}_{3}$ results in the released of $\mathrm{H}^{+}$which is a potential source of the increase in soil acidity (Magdoff et al., 1997). This explains the lower soil pH observed in the higher rates of urea. Muhammad Zaid et al. (2014) reported a lower soil $\mathrm{pH}$ in oil palm plantations due to acidifying effects of ammonium compared to non-cultivated areas. The findings of this study is congruent with that of Chan et al. (2007) who reported that $100 \mathrm{t} \mathrm{ha}^{-1}$ biochar application to Alfisols resulted in an increase in soil $\mathrm{pH}$ by 1.22 units in the absence of $\mathrm{N}$ fertilizer but the corresponding increase was only 0.61 units with the application of $\mathrm{N}$ fertilizer.

In the second planting cycle (Table 3), biochar main treatment effects on soil pH showed that soil applied with $20 \mathrm{t} \mathrm{ha}^{-1}$ biochar resulted in significantly higher soil $\mathrm{pH}$ (4.28). Adding $10 \mathrm{t}$ ha- biochar did not significantly increase soil $\mathrm{pH}$ and soil without biochar treatments resulted in the lowest soil $\mathrm{pH}$ (4.07).

The effects of clinoptilolite zeolite diminished in the second planting cycle as biochar main effects alone showed significant increase in soil pH. This indicates that the effects of biochar sustains longer compared with zeolite. Increase in soil $\mathrm{pH}$ observed in biochar treated soil may be due to the high ash content of biochar which has the ability to neutralize acidic soils (Nigussie et al., 2012). Increase in soil pH from 4-6 to 6-7 was reported by Cornelissen et al. (2013) with 5\% wood biochar application in Ultisols. An increase in soil pH by 0.52 units with $12 \mathrm{t} \mathrm{ha}^{-1}$ biochar treatment in a moderately acidic Ultisols Kandiudults in Ethiopia was documented by Abewa et al. (2014). Novak et al. (2009) reported an increase in soil pH up to 64\% with poultry litter biochar applied at $40 \mathrm{t} \mathrm{ha}^{-1}$ in Norfolk Typic Kandiudults. The rise in $\mathrm{pH}$ was attributed to the alkaline oxides or carbonates formed during biochar pyrolysis, that released into the soil and reacted with $\mathrm{H}^{+}$and $\mathrm{Al}^{3+}$, thus reducing the exchangeable acidity.

The decrease in soil acidity when biochar is applied may also be the result of decrease in exchangeable aluminium ions in the soil. Aluminium ions $\left(\mathrm{Al}^{3+}\right)$ are the dominant cations in majority of soils with $\mathrm{pH}$ less than 5 (Coleman and Thomas, 1967). Nigussie et al. (2012) recorded an increase by $9 \%$ in soil pH with $10 \mathrm{t}$ $\mathrm{ha}^{-1}$ maize stalk biochar amendment and the increase was attributed to the high surface area and porous characteristics of biochar that elevates cation exchange capacity thus, resulting in a possibility for $\mathrm{Al}$ and $\mathrm{Fe}$ to bind with the exchange sites of soils thus decreasing the exchangeable $\mathrm{Al}$ and $\mathrm{Fe}$ in biochar treated soil. Chan et al. (2007) reported an increase in soil pH by 1.22 units when biochar is applied and the increase in $\mathrm{pH}$ was accompanied by a decrease in exchangeable $\mathrm{Al}$ by more than $50 \%$ at 50 and $100 \mathrm{t} \mathrm{ha}^{-1}$ biochar treatments.

In the first planting cycle, higher soil total CEC was observed in soil treated with $20 \mathrm{t} \mathrm{ha}^{-1}$ biochar $\left(7.85 \mathrm{cmol}^{+}\right.$ $\mathrm{kg}^{-1}$ ) (Table 3). The increase in CEC with $10 \mathrm{t} \mathrm{ha}^{-1}$ biochar was not significant $\left(5.68 \mathrm{cmol}^{+} \mathrm{kg}^{-1}\right)$ compared to that of the unamended soil. Cation exchange capacity was lowest in the unamended soil $\left(5.16 \mathrm{cmol}^{+} \mathrm{kg}^{-1}\right)$. In the second planting cycle, amending soil with $20 \mathrm{t} \mathrm{ha}^{-1}$ biochar resulted in significantly higher CEC (12.36 $\left.\mathrm{cmol}^{+} \mathrm{kg}^{-1}\right)$ and untreated soil resulted in the lowest CEC $\left(7.43 \mathrm{cmol}^{+} \mathrm{kg}^{-1}\right)$. Cation exchange capacity of the soil treated with $10 \mathrm{t} \mathrm{ha}^{-1}$ biochar was $9.40 \mathrm{cmol}^{+} \mathrm{kg}^{-1}$.

The increase in cation exchange capacity in the biochar treated soil was possibly due to the increase of net negative charges at the surface of biochar which attracts the positive cations, thus increasing the soil CEC. Glaser et al. (2003) attributed the higher net negative charge of the anthropogenic soils rich in black carbon from Brazillian Amazon (the origin of biochar) to oxidation of the aromatic $\mathrm{C}$ and formation of carboxyl group at biochar surface. Lehmann et al. (2005) suggested that such formation of carboxyl groups or other functional groups with net negative charge might be from the outcome of two varied processes which were surface oxidation of the biochar particles themselves and/or adsorption of highly oxidised organic matter onto the biochar surface. Liang et al. (2006) concluded that oxidation increased from the biochar's core to the surface and non-biochar particles may be adsorbed on the surface of biochar particles creating highly oxidised surface. As a result of both oxidations, the charge density or potential CEC per unit surface area was increased.

The increase in $\mathrm{pH}$ in biochar treated soil may also related to the soil CEC. Soil $\mathrm{pH}$ influenced variable charges of soil minerals of Oxisols and Ultisols. As pH increased, the minerals became net-negatively charge which results in increase in soil CEC as the net-negative charges attract positively charged cations minerals 
(Shamshuddin and Daud, 2011). The increase in CEC with the increase of pH was also reported by Shamshuddin and Ishak (2010).

Unlike in the first planting cycle, soil CEC was higher in the second planting cycle (Table 3). This could be due to heavy rain in the first planting cycle which may have leached out the cations compared to minimal rain in the second planting cycle. There is also a possibility that the higher CEC in the second planting cycle could be partly due to the aging of biochar. The CEC of biochar has been shown to increase as biochar ages (Cheng et al., 2008) because of an increase in some oxygenated functional groups on the surface of the biochar (Cheng et al., 2006). The increase in CEC in this study due to biochar application is similar to the results of previous researches such as Nigussie et al. (2012) who observed a significant increase in soil CEC by 30\% with biochar application in the soil. Cornelissen et al. (2013) also reported a significant improvement in soil CEC in soil treated with biochar in maize farming sites in Zambia. Sukartono et al. (2011) documented an increase in soil CEC by $13 \%$ for the application of $15 \mathrm{t} \mathrm{ha}^{-1}$ coconut shell biochar in a sandy soil of Lombok, Indonesia. Chan et al. (2007) reported an increase in CEC by $26 \%$ with green waste biochar soil amendment.

Figure 3 represents the significant interaction effects $(\mathrm{P}<0.05)$ of biochar and clinoptilolite zeolite on soil TOC for the first planting cycle. Soil without amendment resulted in lowest soil TOC (1.76\%). The 10 and 20 $\mathrm{t} \mathrm{ha}^{-1}$ biochar increased TOC to 1.99 and 2.59\%, respectively. Total organic C for soil treated with $1.25 \mathrm{t} \mathrm{ha}^{-1}$ zeolite was $2.23 \%$ and TOC increased to 2.23 and $2.28 \%$ when treated with a combination of $1.25 \mathrm{t} \mathrm{ha}^{-1}$ clinoptilolite zeolite with 10 and $1.25 \mathrm{t} \mathrm{ha}^{-1}$ clinoptilolite zeolite with $20 \mathrm{t} \mathrm{ha}^{-1}$ biochar, respectively. The TOC for $2.5 \mathrm{t} \mathrm{ha}^{-1}$ clinoptilolite zeolite treatment was $2.28 \%$. A combination of $2.5 \mathrm{t} \mathrm{ha}^{-1}$ zeolite with $10 \mathrm{t} \mathrm{ha}^{-1}$ biochar increased soil TOC to $3.02 \%$ and soil TOC was the highest $(3.98 \%)$ when the same rate of clinoptilolite zeolite combined with higher rate of biochar $\left(20 \mathrm{t} \mathrm{ha}^{-1}\right)$. In the second planting cycle, the biochar main treatment effects on soil TOC (Table 2) showed that soil treated with $20 \mathrm{t} \mathrm{ha}^{-1}$ bicohar resulted in significantly higher TOC (4.81\%) whereas, soil without biochar resulted in the lowest TOC (3.32\%). The TOC for soil treated with $10 \mathrm{t} \mathrm{ha}^{-1}$ biochar was $4.15 \%$ but the result was not significantly different from no biochar treatment.

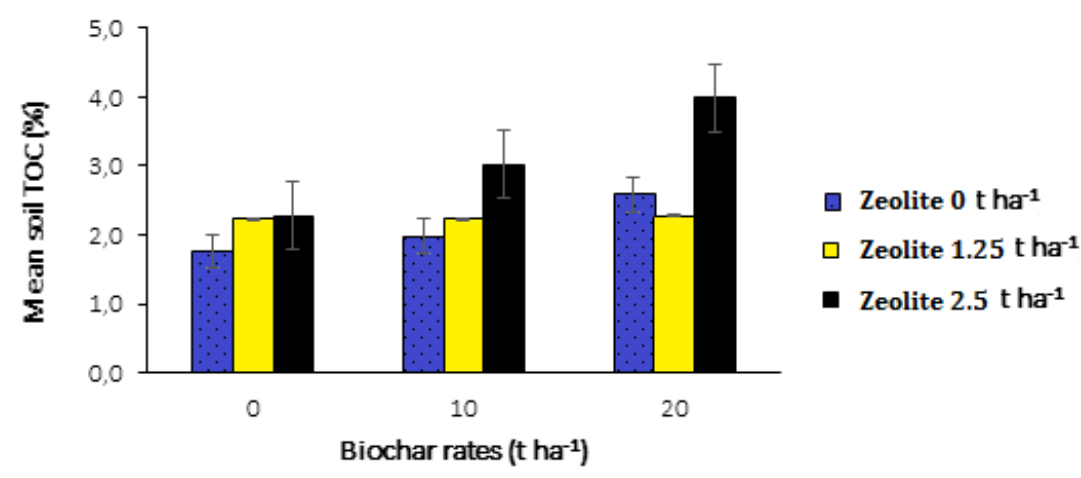

Figure 3. Interaction effect between biochar and clinoptilolite zeolite for soil total organic $\mathrm{C}$ for the first planting cycle. Error bars indicates standard error.

For the first planting cycle, soil TOC increased linearly with increasing rates of both biochar and clinoptilolite zeolite amendments. The increase in soil $\mathrm{pH}$ with biochar and clinoptilolite zeolite treatments may have influenced the increase in soil organic $C$ by favouring microbial decomposition activities, thus resulting in increased total organic C. However, for the second planting cycle only biochar showed significant main effects on soil TOC (Table 3). This could be due to the recalcitrant effects of biochar over time compared with clinoptilolite zeolite. The organic $\mathrm{C}$ in the soil was also influenced by the quality and quantity of organic matter input into the soil (FAO, 2005). The higher soil TOC in plots amended with biochar could be due to the high inherent content of carbon in the biochar, as biochar itself is a term reserved for biomass derived materials contained within the black carbon (BC) continuum (Lehmann et al., 2006). Higher organic C was observed in a Terra Preta soil in Brazillian Amazon which is rich in black carbon or biochar compared to the adjacent soil (Liang et al., 2006). Novak et al. (2009) also reported higher soil organic C in biochar treated soils. These findings are also supported by the results of Sukartono et al. (2011) who reported an increase of soil organic $\mathrm{C}$ by $27 \%$ with $15 \mathrm{t} \mathrm{ha}^{-1}$ biochar treatment. Zhang et al. (2011) reported an increase of soil organic C by 25 and $42 \%$ with 20 and $40 \mathrm{t} \mathrm{ha}^{-1}$ biochar amendments compared with no biochar treatment with urea. Without urea addition, soil organic C was reported to increase by 44 and $58 \%$ with 20 and $40 \mathrm{t}$ ha-1 biochar treatments, respectively.

Kimetu et al. (2008) also reported that the application of biochar increased the SOC by $45 \%$. The addition of biochar increased the soil organic matter as the biochar itself is a component of soil organic matter (Kimetu 
et al., 2008). Sinclair et al. (1994) observed an increase in soil C by $0.5 \%$ with $10 \mathrm{t} \mathrm{ha}^{-1}$ biochar application. Soil total C was increased from $3.57 \%$ to $4.50 \%$ in Oxisols with $10 \mathrm{t} \mathrm{ha}^{-1}$ papermill waste biochar amendment in a study conducted by van Zwieten et al. (2010). An increase of soil TOC by $11 \%$ was also reported by Abewa et al., (2014) with $12 \mathrm{t} \mathrm{ha}^{-1}$ amendment in a Northwestern Ethiopia Ultisols and Prabha et al. (2013) observed an increase in soil organic $\mathrm{C}$ by $13 \%$ with biochar treatment under rice cultivation.

\section{Soil available phosphorus, exchangeable potassium, calcium, and magnesium}

There were no significant interaction effects between all the three factors on soil available $\mathrm{P}, \mathrm{K} \mathrm{Ca}$ and $\mathrm{Mg}$ irrespective of planting cycle (Table 4). In the first planting cycle, only biochar showed significant on main treatment effects for soil available $\mathrm{P}$, so was exchangeable $\mathrm{K}$ and $\mathrm{Mg}$. In the second planting cycle, soil available $\mathrm{P}$ and exchangeable $\mathrm{K}$ was affected by biochar main treatment effects whereas the biochar and zeolite main treatment effects significantly affected soil exchangeable $\mathrm{Mg}$. All the treatments showed no significant effects on soil exchangeable Ca in the second planting cycle.

In the first planting cycle, soil treated with $20 \mathrm{t} \mathrm{ha}^{-1}$ biochar resulted in significantly higher soil available $\mathrm{P}$ (8.10 mg kg-1). Soil available $\mathrm{P}$ was the lowest in untreated soil $\left(1.38 \mathrm{mg} \mathrm{kg}^{-1}\right)$. Applying $10 \mathrm{t} \mathrm{ha}^{-1}$ biochar increased soil available $\mathrm{P}$ to $3.90 \mathrm{mg} \mathrm{kg}^{-1}$ but the increase was not significant compared to untreated soil. After the second crop, mean separation using LSD test resulted in no significance different in soil available $\mathrm{P}$ between 10 and $20 \mathrm{t} \mathrm{ha}^{-1}$ biochar treatments but both were significantly higher than the $0 \mathrm{t} \mathrm{ha}^{-1}$ biochar treatment by $135.00 \%$ and $111.67 \%$, respectively.

For soil exchangeable $\mathrm{K}, 10 \mathrm{t} \mathrm{ha}^{-1}$ and $20 \mathrm{t}^{\mathrm{h}} \mathrm{h}^{-1}$ biochar treatments significantly increased the soil exchangeable K by $64.30 \%$ and $111.57 \%$, respectively compared with $0 \mathrm{t}^{\mathrm{a}} \mathrm{h}^{-1}$ biochar treatment. Soil without biochar treatment resulted in the lowest soil $\mathrm{K}\left(10.98 \mathrm{mg} \mathrm{kg}^{-1}\right)$. In the second planting cycle, soil exchangeable $\mathrm{K}$ was the highest in $20 \mathrm{t} \mathrm{ha}^{-1}$ biochar treatment $\left(35.74 \mathrm{mg} \mathrm{kg}^{-1}\right)$ while $0 \mathrm{t} \mathrm{ha}^{-1}$ biochar treatment resulted in the lowest soil available $\mathrm{K}\left(23.65 \mathrm{mg} \mathrm{kg}^{-1}\right)$. Soil exchangeable $\mathrm{K}$ for $10 \mathrm{t} \mathrm{ha}^{-1}$ biochar treatment (25.24 $\mathrm{mg} \mathrm{kg}^{-1}$ ) was not significantly different than soil available $\mathrm{K}$ in $0 \mathrm{t} \mathrm{ha}^{-1}$ biochar treatment.

Soil exchangeable Mg was higher in soil treated with 10 and $20 \mathrm{t} \mathrm{ha}^{-1}$ compared with soil without biochar application. Unamended soil resulted in the lowest soil $\mathrm{Mg}\left(74.06 \mathrm{mg} \mathrm{kg}^{-1}\right)$. In the second planting cycle, biochar main treatment effects on soil exchangeable $\mathrm{Mg}$ showed that the 10 and $20 \mathrm{t} \mathrm{ha}^{-1}$ biochar $^{-1}$ amendments resulted in no significant difference in soil exchangeable Mg but both were significantly higher by 9.49 and $14.12 \%$, respectively, compared to $0 \mathrm{t} \mathrm{ha}^{-1}$ biochar treatment. For clinoptilolite zeolite main treatment effects, soil exchangeable $\mathrm{Mg}$ in soil treated with zeolite at 1.25 and $2.5 \mathrm{tha}^{-1}$ did not show significant difference but both were significantly higher by $6.06 \%$ and $6.02 \%$, respectively, compared with the $0 \mathrm{t} \mathrm{ha}^{-1}$ zeolite treatment.

Soil available $\mathrm{P}$ was increased with biochar application after both crops. Given the low $\mathrm{pH}$ of the field, increase in soil $\mathrm{P}$ availability may also be the result of increasing $\mathrm{pH}$ in biochar treated soil. At low soil $\mathrm{pH}, \mathrm{Al}$ concentration in soil solution is higher which may lead to the formation of Al phosphate that can be precipitated or strongly adsorbed in the soil causing a reduction in P availability (von Uexkull, 1986). Shamshuddin and Ishak (2010) reported a decrease in exchangeable Al with increasing soil pH. The increase in $\mathrm{pH}$ may reduce the activity of $\mathrm{Al}$, thus contributing to increase in P availability (Shamshuddin et al., 2011).

In a related study, Widowati et al. (2012) reported an increase in soil available P by $28 \%$ with biochar treatment in maize field trials. Liang et al. (2006) observed a higher P concentration at all four sites of carbon-rich Anthrosols of the Brazillian Amazon compared to non carbon-rich adjacent soils. Nigussie et al. (2012) reported an increase in P availability with the application of $10 \mathrm{t} \mathrm{ha}^{-1}$ maize stalk biochar in soil planted with lettuce. Fellet et al. (2011) reported an increase in soil P concentration in main tailing soil from $81.8 \mathrm{mg} \mathrm{kg}^{-1}$ to $445 \mathrm{mg} \mathrm{kg}^{-1}$ with $10 \%$ biochar addition to the soil and remarkably higher $\mathrm{P}$ concentration by $179-208 \%$ in biochar treated soil was observed by Widowati and Asnah (2014).

In the second planting cycle biochar treatments resulted in significant effects on soil available $\mathrm{K}$ and $\mathrm{Mg}$. Available $\mathrm{K}$ and $\mathrm{Mg}$ occur in the form of cations $\left(\mathrm{K}^{+}\right.$and $\left.\mathrm{Mg}^{2+}\right)$ in the soil solution. The increase of both cations can be explained by the increase of $\mathrm{pH}$ and CEC with biochar application. As $\mathrm{pH}$ increases, the net negative charge of variable clay in Oxisols and Ultisols increase (Sanchez and Logan, 1992; Shamshuddin and Daud, 2011). This in turn will increase the soil CEC and adsorption of cations. Biochar also possess the ability to adsorb cations due to its high net negative surface charge and adsorption affinity of cations (Liang et al., 2006). This will result in cations flush on the surface of biochar thus increasing the availability of cationic species in biochar treated soil. 
S.W. Zaidun et al. / Eurasian J Soil Sci 2019, 8 (1) 1 - 10

Table 4. Soil available nutrients as affected by biochar, clinoptilolite zeolite, and urea in the first and second planting cycles

\begin{tabular}{|c|c|c|c|c|c|c|c|c|}
\hline & \multicolumn{4}{|c|}{ First Planting Cycle } & \multicolumn{4}{|c|}{ Second Planting Cycle } \\
\hline & Avail. P & $\begin{array}{l}\text { Exch. K } \\
\left(\mathrm{mg} \mathrm{kg}^{-1}\right)\end{array}$ & Exch. Ca & Exch. Mg & Avail. P & Exch. K & $\begin{array}{l}\text { Exch. Ca } \\
\left(\mathrm{mg} \mathrm{kg}^{-1}\right)\end{array}$ & Exch. Mg \\
\hline \multicolumn{9}{|c|}{ Biochar (t ha-1) } \\
\hline 0 & $1.38^{\mathrm{b}}$ & $10.98^{\mathrm{b}}$ & $181.12^{\mathrm{a}}$ & $74.06^{c}$ & $1.80^{\mathrm{a}}$ & $23.65^{b}$ & $199.44^{a}$ & $81.68^{b}$ \\
\hline 10 & $3.90^{\mathrm{b}}$ & $18.04^{\mathrm{a}}$ & $157.44^{\mathrm{a}}$ & $86.39^{b}$ & $4.23^{b}$ & $25.24^{\mathrm{b}}$ & $206.44^{\mathrm{a}}$ & $89.43^{a}$ \\
\hline 20 & $8.10^{\mathrm{a}}$ & $23.23^{\mathrm{a}}$ & $192.73^{a}$ & $95.61^{\mathrm{a}}$ & $3.81^{b}$ & $35.74^{\mathrm{a}}$ & $217.31^{a}$ & $93.22^{\mathrm{a}}$ \\
\hline $\mathrm{P}$ & $<0.01$ & $<0.01$ & 0.65 & $<0.01$ & 0.02 & 0.02 & 0.16 & $<0.01$ \\
\hline Std. Error & \pm 1.34 & \pm 2.30 & \pm 27.38 & \pm 2.87 & \pm 0.60 & \pm 3.22 & \pm 6.43 & \pm 1.44 \\
\hline \multicolumn{9}{|c|}{ Zeolite (t ha-1) } \\
\hline 0 & $5.10^{\mathrm{a}}$ & $19.58^{\mathrm{a}}$ & $164.53^{\mathrm{a}}$ & $80.94^{a}$ & $3.41^{\mathrm{a}}$ & $28.48^{\mathrm{a}}$ & $205.13^{\mathrm{a}}$ & $84.70^{\mathrm{b}}$ \\
\hline 1.25 & $4.31^{\mathrm{a}}$ & $18.32^{\mathrm{a}}$ & $142.37^{a}$ & $90.12^{\mathrm{a}}$ & $3.72^{\mathrm{a}}$ & $27.33^{a}$ & $213.71^{\mathrm{a}}$ & $89.83^{a}$ \\
\hline 2.5 & $3.98^{\mathrm{a}}$ & $14.35^{\mathrm{a}}$ & $224.39^{a}$ & $84.99^{a}$ & $2.71^{\mathrm{a}}$ & $28.81^{\mathrm{a}}$ & $204.36^{a}$ & $89.80^{a}$ \\
\hline $\mathrm{P}$ & 0.83 & 0.26 & 0.11 & 0.09 & 0.48 & 0.94 & 0.53 & 0.02 \\
\hline Std. Error & \pm 1.34 & \pm 2.30 & \pm 27.38 & \pm 2.87 & \pm 0.60 & \pm 3.22 & \pm 6.43 & \pm 1.44 \\
\hline \multicolumn{9}{|c|}{ Urea (kg ha-1) } \\
\hline 60 & $4.83^{a}$ & $15.97^{\mathrm{a}}$ & $172.92^{\mathrm{a}}$ & $84.74^{a}$ & $3.01^{\mathrm{a}}$ & $27.16^{\mathrm{a}}$ & $205.16^{a}$ & $88.89^{a}$ \\
\hline 120 & $4.09^{a}$ & $18.86^{\mathrm{a}}$ & $181.28^{a}$ & $85.96^{a}$ & $3.55^{\mathrm{a}}$ & $29.26^{a}$ & $210.31^{a}$ & $87.33^{a}$ \\
\hline $\mathrm{P}$ & 0.64 & 0.28 & 0.79 & 0.71 & 0.45 & 0.58 & 0.49 & 0.35 \\
\hline Std. Error & \pm 1.09 & \pm 1.88 &. \pm 22.35 & \pm 2.34 & \pm 0.49 & \pm 2.63 & \pm 5.23 & \pm 1.18 \\
\hline
\end{tabular}

Means with the same letter within the columns are not significantly different $(\mathrm{P}<0.05)$ using LSD test. $P=$ probability value from ANOVA.

Increase in soil $\mathrm{K}$ by up to $189 \%$ with biochar treatment was reported by Widowati et al. (2012) and in a study by Widowati and Asnah (2014), soil available K was observed to be higher (69-89\%) as a result of biochar treatment. Soil $\mathrm{K}$ was observed to be higher by up to $14 \%$ with biochar treatment in an experiment conducted by Nigussie et al. (2012). In an experiment conducted by Sukartono et al. (2011), $15 \mathrm{t} \mathrm{ha}^{-1}$ biochar treatment increased soil $\mathrm{K}$ by $11 \%$ and an increase in soil $\mathrm{K}$ with biochar application in Colombian Savanna Oxisols was observed by Major et al. (2010). Fellet et al. (2011) also observed an increase in soil K from 38.2 $\mathrm{mg} \mathrm{kg}^{-1}$ in nutrient poor mine tailing soil to $2398 \mathrm{mg} \mathrm{kg}^{-1} \mathrm{~K}$ with $10 \%$ biochar addition. Prabha et al. (2013) recorded a higher soil available $\mathrm{K}$ by $29 \%$ with biochar application under rice cultivation.

Major et al. (2010) reported an increment of soil Mg by 64 to $217 \%$ in a Colombian Savanna Oxisols with $20 \mathrm{t}$ ha $^{-1}$ biochar treatment compared to soil without biochar treatment. Nigussie et al. (2012) however reported a lower percentage of soil Mg increment (by 8\%) with $10 \mathrm{t} \mathrm{ha}^{-1}$ biochar in a Southwest Ethiopia Ultisols. An increase by $17 \%$ of soil Mg was documented by Sukartono et al. (2011) with $15 \mathrm{t} \mathrm{ha}^{-1}$ coconut shell biochar application. After the second crop, zeolite showed significant main effects on soil Mg. Zeolite is manufactured made from alkaline earth mineral possessing net negative surface charge, high cation exchange capacity and high cations adsorption ability (Sand and Mumpton, 1978). Zeolite also has the ability to trap small cations and inhibiting the cations from being leached out. The increase in exchangeable $\mathrm{Mg}$ in the soil with zeolite application may be the result of these features of zeolite. This result is supported by the finding of Rădulescu (2013) who also reported an increase of soil mg by up to $72.8 \%$ with zeolite application under oat cultivation.

\section{Conclusion}

Biochar produced from EFB-POME increased soil total $\mathrm{N}, \mathrm{P}, \mathrm{K}, \mathrm{Ca}$ and $\mathrm{Mg}$ contents compared with clinoptilolite zeolite. The higher of soil total $\mathrm{N}, \mathrm{P}, \mathrm{K}, \mathrm{Ca}$ and $\mathrm{Mg}$ could be related to the increase in soil $\mathrm{pH}$, cation exchange capacity, and total organic carbon in biochar treated soil. EFB-POME biochar was more suitable to be used in a tropical soil (Typic Paleudults) compared with clinoptilolite zeolite for improving the selected soil chemical properties. Over time, only biochar treatments showing improvement on soil properties as it can be seen in the results of second cycle planting where contrary to biochar, soil treated with zeolite did not show any significant different on soil properties.

\section{Acknowledgment}

The authors would like to thank the Ministry of Higher Education Malaysia for funding the project and Universiti Malaysia Sabah for technical support.

\section{References}

Abewa, A., Yitaferu, B., Selassie, Y.G., Amare, T., 2014. The role of biochar on acid soil reclamation and yield of teff (Eragrostis tef (Zucc) Trotter) in Northwestern Ethiopia. Journal of Agricultural Sciences 6(1): 1-12. 
Acres, B.D, Bower, R.P., Burrough, P.A., Folland, C.J., Kalsi, M.S., Thomas, P., Wright, P.S., 1975. The Soils of Sabah, Vol. 5. Land Resources Division, Ministry of Overseas Development. England. 147p.

Akbar, S., Khatoon, S., Shehnaz, R., Hussain, T., 1999. Natural zeolites: Structures, classification, origin, occurrence and importance. Science International (Lahore) 11(1): 73-78.

Anda, M., Shamshuddin, J., Fauziah, C.I., Syed Omar, S.R. 2008. Mineralogy and factors controlling charge development of three oxisols developed from different parent materials. Geoderma 143(1-2): 153-167.

Basiron, Y., Weng, C.K., 2004. The oil palm and its sustainablity. Journal of Oil Palm Research 16(1): 1-10.

Bazmi, A.A., Zahedi, G., Hashim, H., 2011. Progress and challenges in utilization of palm oil biomass as fuel for decentralized electricity generation. Renewable and Sustainable Energy Reviews 15(1): 574-583.

Chan, K.Y., Zwieten, L.V., Meszaros, I., Downie, A., Joseph, S., 2007. Agronomic values of greenwaste biochar as a soil amendment. Australian Journal of Soil Research 45(8): 629-634.

Cheng, C. H., Lehmann, J., Engelhard, M., 2008. Natural oxidation of black carbon in soils: Changes in molecular form and surface charge along a climosequence. Geochimica et Cosmochimica Acta 72(6): 1598-1610.

Cheng, C.H., Lehmann, J., Thies, J. E., Burton, S.D., Engelhard, M.H., 2006. Oxidation of black carbon by biotic and abiotic processes. Organic Geochemistry 37(11): 1477-1488.

Coleman, N.T., Thomas, G.W., 1967. The Basic Chemistry of Soil Acidity. In: Soil Acidity and Liming. Pearson, R.W., Adams, F. (Eds.). American Society of Agronomy. Wisconsin, Madison, USA. pp.1-41

Cornelissen, G., Martinsen, V., Shitumbanuma, V., Alling, V., Breedveld, G.D., Rutherford, D.W., Sparrevik, M., Hale, S.E., Obia, A., Mulder, J., 2013. Biochar effect on maize yield and soil characteristics in five conservation farming sites in Zambia. Agronomy 3(2): 256-274.

FAO, 2005. The importance of soil organic matter. Key to drought-resistant soil and sustained food production. FAO Soils Bulletin 80. Food and Agriculture Organization of the United Nations, Rome, Italy. 80p. Available at [access date: 26.01.2018]: http://www.fao.org/3/a-a0100e.pdf

Fellet, G., Marchiol, L., Delle Vedova, G., Peressotti, A., 2011. Application of biochar on mine tailings: Effects and perspectives for land reclamation. Chemosphere 83(9): 1262-1267.

Glaser, B., Guggenberger, G., Zech, W., Ruivo, M.L., 2003. Soil organic matter stability in Amazonian Dark Earths. In: Amazonian Dark Earths: Origin, Properties, Management. Lehmann, J. Kern, D.C., Glaser, B., Woods, W.I. (Eds.). Kluwer Academic Publishers, Dordrecht, Netherlands. pp.227-241.

IFA, 2014. Fertilizer Outlook 2014-2018. Institute of Fertilizer Industry Association (IFA). 82nd IFA Annual Conference. 26-28 May 2014, Sydney, Australia. Available at [access date: 26.01.2018]: https://www.fertilizer.org//images/Library_Downloads/2014_ifa_sydney_summary.pdf

Karhu, K., Mattila, T., Bergström, I., Regina, K., 2011. Biochar addition to agricultural soil increased CH4 uptake and water holding capacity - Results from a short-term pilot field study. Agriculture, Ecosystems and Environment 140(1-2): 309-313.

Kimetu, J.M., Lehmann, J., Ngoze, S.O., Mugendi, D.N., Kinyangi, J.M., Riha, S., Verchot, L., Recha, J.W., Pell, A.N. 2008. Reversibility of soil productivity decline with organic matter of differing quality along a degradation gradient. Ecosystems 11:726-739.

Lehmann, J., Gaunt, J., Rondon, M., 2006. Biochar sequestration in terrestrial ecosystems - a review. Mitigation and Adaptation Strategies for Global Change 11(2): 403-427.

Lehmann, J., Joseph, S. 2009. Biochar for environmental management: an introduction. In: Biochar for Environmental Management: Science and Technology. Lehmann, J., Joseph, S. (Eds.). Earthscan, London, UK. pp. 1-12.

Lehmann, J., Liang, B., Solomon, D, Lerotic, M., Luizão, F., Kinyangi, J., Schäfer, T., Wirick, S and Jacobsen, C. 2005. Nearedge X-ray absorption fine structure (NEXAFS) spectroscopy for mapping nano-scale distribution of organic carbon forms in soil: Application to black carbon particles. Global Biogeochemical Cycles 19(1): GB1013.

Lehmann, J., Rillig, M.C., Thies, J., Masiello, C.A., Hockaday, W.C., Crowley, D., 2011. Biochar effects on soil biota - A review. Soil Biology and Biochemistry 43(9): 1812-1836.

Liang, B., Lehmann, J., Solomon, D., Kinyangi, J., Grossman, J., O’Neill, B., Skjemstad, J. O., Thies, J., Luizão, F.J., Peterson, J., Neves, E.G., 2006. Black carbon increases caution exchange capacity in soils. Soil Science Society of America Journal 70(5): 1719-1730.

Magdoff, F., Lanyon, L., Liebhardt, B., 1997. Nutrient cycling, transformations and flows: Implications for more sustainable agriculture. Advances in Agronomy 60: 1-73.

Major, J., Rondon, M., Molina, D., Riha, S.J., Lehmann, J., 2010. Maize yield and nutrition during 4 years after biochar application to a Colombian savanna oxisol. Plant and Soil 333(1-2): 117-128.

Muhammad Zaid, M.K., Shaharudin, B., Sharakbah, Y., 2014. Prolong usage pf inorganic fertilizer in relation to soil acidity. Proceedings of the Soil Science Society Conference of Malaysia. "Soil Management and Environment". 810 April 2014. Kangar, Perlis, Malaysia.

Navrotsky, A., Petrovic, I., Chen, C.Y., Davis, M.E., 1995. Energetics of microporous materials. Journal of Non-Crystalline Solids 192\&193: 474-477.

Nigussie, A., Kissi, E., Misganaw, M., Ambaw, G., 2012. Effect of biochar application on soil properties and nutrient uptake of lettuces (Lactuca sativa) grown in chromium polluted soils. American-Eurasian Journal of Agriculture and Environmental Science 12(3): 369-376. 
Novak, J.M., Lima, I., Xing, B., Gaskin, J.W., Ahmedna, M., Rehra, D., Watss, D.W., Busscher, W.J., Schimberg, H., 2009. Characterization of designer biochar produced at different temperatures and their effects on a loamy sand. Annals of Environmental Science 3: 195-206.

Pansu, M., Gautheyrou, J., 2006. Handbook of soil analysis. Mineralogical, organic and inorganic methods. Springer, Berlin, Heidelberg, The Netherlands. 993p.

Polat, E., Karaca, M., Demir, H., Naci Onus, A., 2004. Use of natural zeolite (Clinoptilolite) in Agriculture. Journal of Fruit and Ornamental Plant Research 12:183-189.

Prabha, S.V., Renuka, R., Sreekanth, N.P., Padmakumar, B., Thomas, A.P., 2013. A study of the fertility and carbon sequestration potential of rice soil with respect to the application of biochar and selected amendments. Annals of Environmental Science 7: 17-30.

Rădulescu, H., 2013. Soil treatment effects of zeolitic volcanic tuff on soil fertility. Research Journal of Agriculture Science 45(2): 238-244.

Sanchez, P.A., Logan, T.J., 1992. Myths and science about the chemistry and fertility of soils in the tropics. In: Chemistry and fertility of soils. Lal, R., Sanchez, P.A. (Eds.). Soil Science Society of America and American Society of Agronomy. Wisconsin, Madison, USA. pp. 35-46.

Sand, L.B., Mumpton, F.A., 1978. Natural zeolites: occurrence, properties, use. Pergamon Press. New York, USA. 546p.

Scherr, S.J., Yadav, S., 1996. Land Degradation in the Developing World: Implications for Food, Agriculture, and the Environment to the Year 2020. Food, Agriculture, and the Environment Discussion Paper 14. International Food Policy Research Institute. Washington D.C., USA. 35p.

Schlesinger, W.H., 1997. Biogeochemistry: An Analysis of Global Change. Academic Press, San Diego, USA, 588p.

Shamshuddin, J., Fauziah, C.I., Anda, M., Kapok, J., Shazana, M.A.R.S., 2011. Using ground basalt and/or organic fertilizer to enhance productivity of acid soils in Malaysia for Crop Production. Malaysian Journal of Soil Science 15(1): 127-146.

Shamshuddin, J., Ishak C.F., 2010. Fertilizer requirement and management. Weathered tropical soils the ultisols and oxisols. Universti Putra Malaysia Press 9: 137.

Shamshuddin, J., Noordin, W.D. 2011. Classification and management of highly weathered soils in Malaysia for production of plantation crops. In: Principles, Application and Assessment in Soil Science. Burcu, E., Özkaraova, G. (Eds.). InTech Open Access Publisher, Crotia, pp.75-86.

Sinclair, K. Slavich, P., van Zwieten, L., Downie, A., 1994. Productivity and nutrient availability on a ferrosol: Biochar, lime and fertiliser. Proceedings of the 24th Annual Conference of the Grassland Society of NSW."The Grass is Greener". Grassland Society of New South Wales Inc.. 5-6 August 2009. Taree, Australia. pp.119-122.

Sukartono, Utomo, W.H., Kusuma, Z., Nugroho, W.H.İ 2011. Soil fertility status, nutrient uptake, and maize (Zea mays L.) yield following biochar and cattle manure application on sandy soils of Lombok, Indonesia. Journal of Tropical Agriculture 49(1-2): 47-52.

Tan, K.H., 1995. Soil sampling, preparation and analysis. Marcel Dekker Inc. New York. USA. 411p.

Vaccari, F.P., Baronti, S., Lugato, E., Genesio, L., Castaldi, S., Fornasier, F., Miglietta, F., 2011. Biochar as a strategy to sequester carbon and increase yield in durum wheat. European Journal of Agronomy 34(4): 231-238.

van Zwieten, L., Kimber, S., Morris, S., Chan, K.Y., Downie, A., Rust, J., Joseph, S., Cowie, A., 2010. Effects of biochar from slow pyrolysis of papermill waste on agronomic performance and soil fertility. Plant and Soil 327(1-2): 235-246.

von Uexkull, H.R., 1986. Efficient fertilizer use in acid upland soils of the humid tropics. FAO Fertilizer and Plant Nutrition Bulletin 10. Food and Agriculture Organization of the United Nations, Rome, Italy. 80p. Available at [access date: 26.01.2018]: http://www.fao.org/docrep/018/aq356e/aq356e.pdf

Wahab, A.G., Rittgers, C., 2014. Malaysia grain and feed annual 2014. USDA Foreign Agriculture Service, Global Agricultural Information Network. Available at [access date: 26.01.2018]: https://gain.fas.usda.gov/Recent\%20GAIN\%20Publications/Grain\%20and\%20Feed\%20Annual_Kuala\%20Lum pur_Malaysia_3-27-2017.pdf

Widowati, Asnah. 2014. Biochar can enhance potassium fertilization efficiency and economic feasibility of maize cultivation. Journal of Agricultural Science 6(2): 24-32.

Widowati, Utomo, W.H., Guritno, B., Soehono, L.A., 2012. The effects of biochar on the growth and $\mathrm{n}$ fertiliser requirement of maize (Zea mays L.) in green house experiment. Journal of Agricultural Science 4(5): $255-262$.

Zhang, A., Liu, Y., Pan, G., Hussain, Q., Li, L. Zheng, J., Zhang, X., 2011. Effect of biochar amendment on maize yield and greenhouse gas emissions from a soil organic carbon poor calcareous loamy soil from Central China Plain. Plant and Soil 351(1-2): 263-275. 